\title{
Perlakuan Rizobakteri Pada Dua Varietas Tomat (Lycopersicum esculentum Mill.) Terhadap Patogen Terbawa Benih dan Peranannya Dalam Pemacu Pertumbuhan Tanaman
}

\author{
Treatment of Rizobakteri In Two Tomato Varieties (Lycopersicum esculentum Mill.) \\ to pathogen carried seed and its role plant growth promoting
}

\author{
Amelia Syahdani ${ }^{1}$,Siti Hafsah ${ }^{1}$ dan Syamsuddin ${ }^{1 *}$ \\ ${ }^{1}$ Program Studi Agroteknologi, Fakultas Pertanian, Universitas Syiah Kuala
}

\begin{abstract}
Abstrak. Tomat merupakan salah satu produk hortikultura yang sangat banyak diminati di kalangan masyarakat karena dapat dimanfaatkan sebagai bumbu masakan, pewarna makanan, kosmetik dan obat-obatan, namun tanaman ini sering diserang oleh organisme pengganggu tanaman khususnya penyakit. Perlakuan benih secara hayati (Biological Seed Treatment) menggunakan rizobakteri merupakan salah satu inovasi yang dikembangkan untuk pengendalian penyakit dan pemacu pertumbuhan tanaman. Penelitian ini telah dilaksanakan di Laboratorium Ilmu dan Teknologi Benih Program Studi Agroteknologi Fakultas Pertanian Unsyiah. Penelitian dimulai sejak bulan Mei hingga Agustus 2017. Penelitian ini menggunakan Rancangan Acak Lengkap (RAL) pola non faktorial pada percobaan I terdiri dari 18 perlakuan yang diulang sebanyak 3 kali sehingga didapatkan masing-masing 54 satuan percobaan terhadap patogen Rhizoctonia solani dan 54 satuan percobaan terhadap patogen Sclerotium rolfsii sehingga didapatkan 108 total satuan percobaan. Pada perobaan II menggunakan Rancangan Acak Lengkap (RAL) pola faktorial terdiri dari 19 perlakuan rizobakteri dan 2 perlakuan varietas yang diulang sebanyak 2 kali Sehingga terdapat 38 kombinasi perlakuan yang terdiri dari 48 unit percobaan dengan 25 unit tanaman di setiap perlakuan. Hasil pengujian in vitro percobaan I dengan menggunakan metode uji kultur ganda dari 18 isolat rizobakteri terdapat lima isolat yang berpotensi sebagai agens biokontrol dengan memiliki daya hambat paling efektif yaitu HWI 4(1), HWI 5(1), HWI 5(4), HWI 8(6) dan BS3 4(5) terhadap Rhizoctonia solani namun memiliki daya hambat yang relatif rendah terhadap patogen Sclerotium rolfsii. Sedangkan pada Hasil penelitian percobaan II menunjukkan bahwa isolat yang efektif sebagai rizobakteri pemacu pertumbuhan tanaman (RPPT) terhadap proses perkecambahan benih tomat dalam meningkatkan viabilitas dan vigor benih adalah isolat SRK 5(3) dan HWI 4(5). Pada parameter pertumbuhan bibit isolat SRK 5(5) dan HWI 5(4) cenderung menunjukkan pengaruh yang efektif dibandingkan perlakukan lainnya. Varietas Servo lebih baik dibandingkan varietas Lentana terhadap viabilitas dan vigor benih.
\end{abstract}

Kata kunci : Rizobakteri, Agens biokontrol, RPPT, Rhizoctonia solani, Sclerotium rolfsii

\begin{abstract}
Tomato is one of the most popular horticultural products in the community because it can be used as food spices, food coloring, cosmetics and medicines, but this plant is often attacked by plant pest organisms, especially diseases. Biological Seed Treatment using rhizobacteria is one of the innovations developed for disease control and growth of plants. This research has been carried out in Agricultural Science and Technology Laboratory of Agrotechnology Majors Faculty of Agriculture Unsyiah. The study was conducted from May to August 2017. This study used a Completely Randomized Design (RAL) of non factorial pattern in experiment I consisted of 18 repeated treatments 3 times so that each of 54 experiments on pathogenic Rhizoctonia solani and 54 units of experiments Sclerotium rolfsii pathogens to obtain 108 total unit experiments. In the second experiment using Completely Randomized Design (RAL) the factorial pattern consisted of 19 rhizobacterial treatments and 2 repeated treatments of varieties 2 times. Thus there were 38 treatment combinations consisting of 48 experimental units with 25 plant units in each treatment. In vitro experimental results of experiment I using double culture test method from 18 rizobakteri isolates, there are five isolates that have potential as biocontrol agent with the most effective inhibition of HWI 4 (1), HWI 5 (1), HWI 5 (4), HWI 8 (6) and BS3 4 (5) to Rhizoctonia solani but have relatively low inhibitory resistance to Sclerotium rolfsii pathogens. While the results of the experimental study II showed that the effective isolates as plant growth rhizobacteria (RPPT) on the tomato seed germination process in increasing seed viability and vigor are isolates SRK 5 (3) and HWI 4 (5). In the growth parameters of seed isolates SRK 5 (5) and HWI 5 (4) tended to show an effective effect compared to other treatments. Servo variety is better than Lentana varieties on seed viability and vigor.
\end{abstract}

Keys world : Rizobacteria, Biocontrol agents, RPPT, Rhizoctonia solani, Sclerotium rolfsii 


\section{PENDAHULUAN}

Tomat (Lycoversicum esculentum Mill.) adalah salah satu komoditas pertanian yang sangat bermanfaat bagi tubuh karena mengandung vitamin dan mineral yang diperlukan untuk pertumbuhan dan kesehatan. Buah tomat mengandung karbohidrat, protein, lemak dan kalori. Buah tomat merupakan komoditas multiguna yang berfungsi sebagai sayuran, bumbu masak, buah konsumsi, penambah nafsu makan, bahan pewarna makanan, sampai kepada bahan kosmetik dan obat-obatan (Cahyono, 2008).

Salah satu upaya peningkatan produksi tanaman tomat adalah dengan teknik budidaya yang baik dan pengendalian penyakit dengan benar. Adapun salah satu pengendalian penyakit dengan benar adalah memperhatikan penyakit terbawa benih yang akan menjadi sumber berkembangnya penyakit yang menyebabkan viabilitas dan vigor benih menjadi rendah (Pulungan et al. 2014).

Penelitian sebelumnya melaporkan isolat rizobakteri Bacillus subtilis ST21 mampu menghambat patogen Fusarium oxysporum, Sclerotium rolfsii, Phythophthora capsici dan Rhizoctonia solani secara in vitro pada tanaman tomat sehingga sangat potensial dikembangkan sebagai agens biokontrol (Khaeruni et al., 2010).

Disamping itu, isolat rizobakteri yang diisolasi dari rizosfer tanaman tomat mampu bersimbiosis dengan akar tanaman sehingga mempunyai peran penting dalam pemacu pertumbuhan tanaman. Isolat tersebut dilaporkan dapat menghasilkan hormon pertumbuhan IAA, memfiksasi nitrogen dan berperan dalam pengaktifan mekanisme ketahanan terhadap penyakit. Dalam hal ini rizobakteri dapat menjadi peluang baru sebagai pupuk hayati (Thakuria et al., 2004).

\section{METODE PENELITIAN}

\section{Tempat dan Waktu Penelitian}

Penelitian ini dilaksanakan di Laboratorium Ilmu dan Teknologi Benih, Program Studi Agroteknologi Fakultas Pertanian Universitas Syiah Kuala Darussalam Banda Aceh. Penelitian telah dilaksanakan dari bulan Mei hingga bulan Agustus 2017.

\section{Alat dan Bahan Penelitian}

Alat yang digunakan dalam penelitian ini yaitu Laminar Air Flow Cabinet, jarum ose, erlenmeyer, beaker glass, pinset, lampu bunsen, petridish, gelas ukur, ruang inkubasi, autoclave, timbangan analitik, oven listrik, tray, meja pembibitan, sprayer, meteran, jangka sorong, ayakan 9 mesh dan spektrofotometer. Sedangkan Bahan yang digunakan dalam penelitian ini adalah benih tomat varietas Lentana dan Servo masing-masing sebanyak 1 sachet, isolat patogen Rhizoctonia solani dan Sclerotium rolfsii dan, isolat Rizobakteri yang berasal dari tanaman tomat sebanyak 18 jenis, PDA (Potato Dextrose Agar) 3 L, aluminium foil 1 unit, alkohol $96 \% 2 \mathrm{~L}$, plastic wrap 1 unit, plastik tahan panas, karet, aquadest $10 \mathrm{~L}$, tisu, tanah, dan pupuk kandang.

\section{Rancangan Penelitian}

Dalam penelitian ini dilakukan melalui 2 (dua) percobaan, dimana percobaan I menggunakan Rancangan Acak Lengkap (RAL) pola non faktorial dan percobaan II menggunakan Rancangan Acak Lengkap (RAL) pola faktorial. Pada percobaan I faktor yang diteliti adalah rizobakteri sebanyak 18 isolat yaitu SRK 5(1) $\left(\mathrm{R}_{1}\right)$, SRK 5(2) ( $\left.\mathrm{R}_{2}\right)$, SRK 5(3)

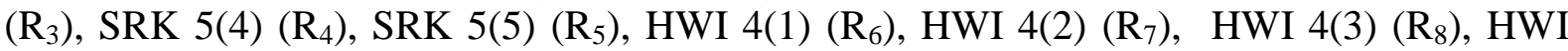

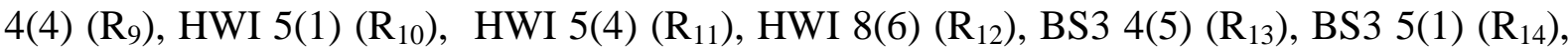


BS3 5(3) ( $\left.\mathrm{R}_{15}\right)$, BS3 5(4) ( $\left.\mathrm{R}_{16}\right)$, KTK 8(4) $\left(\mathrm{R}_{17}\right)$, KTK 8(5) $\left(\mathrm{R}_{18}\right)$ dengan 3 kali ulangan didapatkan 54 satuan percobaan terhadap patogen $R$. Solani dan 54 satuan percobaan terhadap patogen $S$. rolfsii sehingga didapatkan 108 total satuan percobaan. Sedangkan pada percobaan II menggunakan Rancangan Acak Lengkap (RAL) pola faktorial dengan perlakuan rizobakteri yang sama yaitu 18 dan perlakuan varietas Lentana $\left(\mathrm{V}_{1}\right)$ dan Servo $\left(\mathrm{V}_{2}\right)$ yang diulang sebanyak 2 kali Sehingga terdapat 38 kombinasi perlakuan yang terdiri dari 76 unit percobaan dengan 25 unit tanaman di setiap perlakuan.

\section{Prosedur Penelitian}

\section{Percobaan I}

\section{Pembuatan media PDA (Potato Dextrose Agar)}

Menurut Achmad dan Eny (2009) pembuatan media PDA dilakukan dengan menyiapkan potongan kentang ukuran dadu sebanyak $200 \mathrm{~g}$ kemudian direbus dalam $800 \mathrm{ml}$ aquadest sampai tekstur kentang lunak. Air rebusan tersebut disaring dan ditambahkan dextrose sebanyak $20 \mathrm{~g}$ dan agar sebanyak $20 \mathrm{~g}$ disatukan ke dalam erlemenyer yang sudah terisi aquadest hingga mencapai $1 \mathrm{~L}$. Kemudian ditutup dengan menggunakan aluminium foil dan plastik sebanyak 2 lapis serta diikat dengan 3 karet gelang dan disterilkan didalam autoclave selama 15 menit, suhu 121-124 ${ }^{\circ} \mathrm{C}$. Setelah disterilisasi, larutan PDA tersebut dibiarkan hingga suhunya turun menjadi hangat $\left(10-20{ }^{\circ} \mathrm{C}\right)$ dan siap dituang ke dalam petridish. Dan diamkan larutan PDA tersebut hingga memadat dan siap digunakan

\section{Pengujian kultur ganda secara in vitro}

Isolat rizobakteri kandidat agens biokontrol didapatkan dari hasil isolasi sistem perakaran tanaman tomat sehat koleksi Laboratorium Ilmu dan Teknologi Benih Faklutas Pertanian Universitas Syiah Kuala, selanjutnya dilakukan pengujian terhadap patogen terbawa benih menggunakan teknik kultur ganda untuk mengetahui kemampuan antagonismenya. Kultur ganda dipersiapkan dengan cara menempatkan potongan kecil $(0.5 \mathrm{~mm})$ patogen Rhizoctonia solani dan Sclerotium rolfsii, dan rizobakteri ditempatkan pada media PDA dalam petridish dengan jarak $3 \mathrm{~cm}$. (Ainy et al., 2015) yang diinkubasikan pada temperatur ruangan $\left(28-29^{\circ} \mathrm{C}\right)$. Pengamatan dilakukan setiap hari selama 7 hari.

\section{Percobaan II}

\section{Persiapan benih}

Benih yang akan digunakan adalah benih tomat varietas Lentana dan Servo yang diperoleh dari toko Sarana Tani di Lambaro Aceh Besar. Benih ini merupakan varietas unggul dan masih dalam status masa berlaku label hasil pengujian dari produsen benihnya.

\section{Persiapan Isolat Rizobakteri Pemacu Pertumbuhan Tanaman (RPPT)}

Rizobakteri yang digunakan merupakan isolat dari hasil isolasi yang dilakukan oleh peneliti sebelumnya dan merupakan koleksi Laboratorium Ilmu dan Teknologi Benih Fakultas Pertanian Universitas Syiah Kuala. Isolat rizobakteri dikembangbiakkan pada media Potato Dextrose Agar (PDA), selanjutnya diinkubasi selama 48 jam hingga koloni bakteri tumbuh dengan sempurna. Koloni bakteri yang tumbuh disuspensi dalam aquadest steril sebanyak 50 ml. Larutan suspensi bakteri yang telah siap, dihitung kerapatannya dengan menggunakan spektrofotometer sampai mencapai kerapatan populasi $109 \mathrm{cfu} / \mathrm{ml}$ (Bai et al, 2002).

\section{Perlakuan Benih dengan Rizobakteri Pemacu Pertumbuhan Tanaman (RPPT)}

Benih tomat varietas Lentana dan Servo masing-masing sebanyak 25 benih untuk setiap perlakuan, sebelumnya benih dibersihkan dengan cara direndam dalam air dan menggunakan 
aerator selama 24 jam. Selanjutnya benih ditiriskan menggunaan saringan. Benih yang telah dibersihkan kemudian direndam dengan suspensi rizobakteri $150 \mathrm{ml}$ yang sudah disiapkan selama 1 x 24 jam dan siap digunakan untuk pembibitan.

\section{Penanaman Benih}

Benih yang telah mendapatkan perlakuan rizobakteri dikecambahkan menggunakan media tanam berupa campuran tanah dan pupuk kandang steril $(2: 1)$ yang sebelumnya diayak dengan ayakan ukuran 9 mesh. Benih ditanam sebanyak 25 unit pada setiap perlakuan di dalam tray berukuran 27 x 56 x $5 \mathrm{~cm}$ (panjang x lebar x tinggi).

\section{Parameter Pengamatan}

Parameter yang diamati adalah percobaan I : Efektifitas daya hambat rizobakteri. Sedangkan pada percobaan II : viabilitas dan vigor benih meliputi, Potensi tumbuh maksimum (PTM), Daya berkecambah (DB), Indeks vigor (IV), Keserempakan tumbuh (Kst), Kecepatan tumbuh relatif (Kct-R), Waktu yang dibutuhkan untuk mencapai $50 \%$ perkecambahan total relatif $\left(\mathrm{T}_{50}\right)$ dan parameter pertumbuhan bibit meliputi tinggi bibit, diameter batang, jumlah daun, dan berangkasan kering

\section{Analisis Data Penelitian}

Data hasil pengamatan pada setiap peubah dianalisis dengan anova. Data yang menunjukkan perbedaan yang nyata pada Fhitung maka dilanjutkan dengan Uji Beda Nyata Jujur(BNJ) pada taraf 0,05

\section{HASIL DAN PEMBAHASAN}

\section{Percobaan I}

\section{Kemampuan Daya Hambat Rizobakteri terhadap Patogen $R$. solani dan $S$. rolfsii}

Berdasarkan hasil pengamatan rata-rata persentase (\%) daya hambat isolat rizobakteri kandidat agens biokontrol terhadap pertumbuhan koloni patogen terbawa benih tomat secara in vitro pada Tabel 3 terdapat 5 jenis isolat rizobakteri yang memiliki aktifitas daya hambat sedang (51-60\% DH) terhadap koloni patogen $R$. solani yaitu HWI 4(1), HWI 5(1), HWI 5(4), HWI 8(6), BS3 4(5) dengan masing-masing persentasenya 52,59\%, 54,21\%, 56,61\%, $57,63 \%$, dan $54,01 \%$ sedangkan isolat rozobakteri yang sama memiliki daya hambat rendah $(<50 \% \mathrm{DH})$ terhadap koloni patogen $S$. Rolfsii. Terdapat 13 isolat rizobakteri yang memiliki daya hambat rendah $(<50 \%)$ terhadap koloni patogen $R$. solani yaitu SRK 5(1), SRK 5(2), SRK 5(3), SRK 5(4), SRK 5(5), HWI 4(2), HWI 4(3), HWI 4(4), BS3 5(1), BS3 5(3), BS3 5(4), KTK 8(4), KTK 8(5) dengan masing-masing persentasenya 2,87\%. Sedangkan daya hambat rizobakteri terhadap patogen $S$. Rolfsii yang terdapat pada 18 isolat rizobakteri yaitu SRK 5(1), SRK 5(2), SRK 5(3), SRK 5(4), SRK 5(5), HWI 4(1), HWI 4(2), HWI 4(3), HWI 4(4), HWI 5(1), HWI 5(4), HWI 8(6), BS3 4(5), BS3 5(1), BS3 5(3), BS3 5(4), KTK 8(4), KTK 8(5) yang tergolong aktivitas daya hambat rendah $(<50 \% \mathrm{DH})$.

Royanti (2017) melaporkan bahwa isolat BS3 4(5) mampu menghambat koloni patogen Fusarium oxysporum dengan nilai $70 \%$ dan patogen Phytium sp. dengan daya hambat $30 \%$. Namun isolat HWI 4(1) mampu menekan pertumbuhan koloni patogen Fusarium oxysporum dengan nilai 34,45\% (aktivitas rendah $<50 \%$ DH) dan Phytium sp dengan nilai $70 \%$ (aktivitas tinggi $61-75 \% \mathrm{DH}$ ). Hasil penelitian sebelumnya ditemukan bahwa isolat rizobakteri yang berasal dari tanaman tomat sehat dari kelompok Bacillus spp dan kelompok Pseudomonas spp mampu menghasilkan enzim kitinase, sedangkan kelompok rizobakteri Serratia spp menghasilkan senyawan HCN. Kemampuan menghasilkan enzim dan pruduksi 
HCN tersebut sejalan dengan kemampuannya menghambat pertumbuhan koloni patogen $R$. solani asal tomat hasil uji secara in vitro (Syamsuddin, 2010).

Tabel 1. Rata-rata Persentase (\%) Daya Hambat Isolat Rizobakteri Kandidat Agens Biokontrol terhadap Pertumbuhan Koloni Patogen Terbawa Benih Tomat

\begin{tabular}{lcccc}
\hline \multirow{2}{*}{ Agens Biokontrol } & \multicolumn{4}{c}{ Persentase Daya Hambat (\%) } \\
\cline { 2 - 5 } & $\boldsymbol{R}$ solani & Aktivitas & S. rolfsi & Aktivitas \\
\hline SRK 5 (1) & $2,87 \mathrm{a}$ & + & $24,62 \mathrm{cde}$ & + \\
SRK 5 (2) & $2,87 \mathrm{a}$ & + & $22,12 \mathrm{~cd}$ & + \\
SRK 5 (3) & $2,87 \mathrm{a}$ & + & $26,50 \mathrm{cde}$ & + \\
SRK 5 (4) & $2,87 \mathrm{a}$ & + & $29,46 \mathrm{de}$ & + \\
SRK 5 (5) & $2,87 \mathrm{a}$ & + & $27,33 \mathrm{cde}$ & + \\
HWI 4 (1) & $52,59 \mathrm{~b}$ & ++ & $16,06 \mathrm{bc}$ & + \\
HWI 4 (2) & $2,87 \mathrm{a}$ & + & $2,87 \mathrm{a}$ & + \\
HWI 4 (3) & $2,87 \mathrm{a}$ & + & $6,87 \mathrm{ab}$ & + \\
HWI 4 (4) & $2,87 \mathrm{a}$ & + & $22,12 \mathrm{~cd}$ & + \\
HWI 5 (1) & $54,21 \mathrm{~b}$ & ++ & $35,86 \mathrm{e}$ & + \\
HWI 5 (4) & $56,61 \mathrm{~b}$ & ++ & $35,24 \mathrm{e}$ & + \\
HWI 8 (6) & $57,63 \mathrm{~b}$ & ++ & $9,40 \mathrm{ab}$ & + \\
BS3 4 (5) & $54,01 \mathrm{~b}$ & ++ & $30,32 \mathrm{de}$ & + \\
BS3 5 (1) & $2,87 \mathrm{a}$ & + & $8,06 \mathrm{ab}$ & + \\
BS3 5 (3) & $2,87 \mathrm{a}$ & + & $24,75 \mathrm{cde}$ & + \\
BS3 5 (4) & $2,87 \mathrm{a}$ & + & $22,04 \mathrm{~cd}$ & + \\
KTK 8 (4) & $2,87 \mathrm{a}$ & + & $2,87 \mathrm{a}$ & + \\
KTK 8 (5) & $2,87 \mathrm{a}$ & + & $2,87 \mathrm{a}$ & \\
\hline \multicolumn{1}{c}{ BNJ 0,05 } & & 8,06 & &
\end{tabular}

Keterangan : Angka yang diikuti oleh huruf yang sama pada kolom yang sama berbeda tidak nyata pada Uji Beda Nyata Jujur (BNJ) $\alpha=0,05$. Notasi didapatkan dari data transformasi dengan Arc $\sin \sqrt{x}$. Aktivitas sangat tinggi $(++++=>75 \% \mathrm{DH})$, aktivitas tinggi $(+++=61-75 \% \mathrm{DH})$, aktivitas sedang $(++=51-60 \% \mathrm{DH})$, aktivitas rendah $(+=<50 \% \mathrm{DH})$ dan tidak ada aktivitas $(-)$.

\section{Percobaan II}

\section{Kemampuan RPPT Terhadap Viabilitas, Vigor Benih dan Pertumbuhan Bibit}

Hasil analisis ragam (Uji F) menunjukkan bahwa perlakuan rizobakteri bahwa rizobakteri yang diuji berpengaruh sangat nyata terhadap potensi tumbuh maksimum (PTM) dan daya berkecambah (DB). Sedangkan pada parameter keserempakan tumbuh $\left(\mathrm{K}_{\mathrm{ST}}\right)$ berpengaruh nyata pada rizobakteri yang diuji dan berpengaruh tidak nyata pada parameter indeks vigor (IV), kecepatan tumbuh relatif $\left(\mathrm{K}_{\mathrm{CT}}-\mathrm{R}\right)$ dan waktu yang dibutuhkan untuk mencapai $50 \%$ perkecambahan total $\left(\mathrm{T}_{50}\right)$. Sedangkan pada parameter pertumbuhan bibit menunjukkan bahwa jenis rizobakteri yang diuji berpengaruh sangat nyata terhadap tinggi tanaman, jumlah daun dan diameter batang, namun tidak berpengaruh nyata terhadap berangkasan kering.

Pada benih yang memiliki vigor tinggi belum membutuhkan penambahan sumber daya dari luar seperti zat pengatur tumbuh dalam proses invigorasi, disamping itu benih yang digunakan tidak mengalami dormansi. Namun, hasil penelitian Sutariati et al., (2012) melaporkan bahwa perlakuan benih dengan rizobakteri mampu meningkatkan potensi tumbuh maksimum, daya berkecambah, keserempakan tumbuh, dan indeks vigor benih cabai secara signifikan diakibatkan oleh kemampuan isolat rizobakteri tersebut dalam mensintesis hormon tumbuh, memfiksasi nitrogen atau melarutkan fosfat dan Bacillus spp. dilaporkan mampu mensintesis IAA. Menurut Pulungan et al., (2014) vigor benih erat kaitannya dengan pertumbuhan dan produktivitas tanaman. Benih yang memiliki viabilitas dan vigor yang baik akan menghasilkan tanaman normal maksimum melalui penggunaan benih yang bervigor tinggi akan dicapai produksi tanaman yang tinggi pula. 
Tabel 2. Rata-rata Nilai Viabilitas dan Vigor Benih Akibat Perlakuan Beberapa Rizobakteri

\begin{tabular}{ccccccc}
\hline \multirow{2}{*}{ Rizobakteri } & \multicolumn{5}{c}{ Tolok ukur viabilitas dan vigor benih } \\
\cline { 2 - 6 } & PTM $(\%)$ & DB $(\%)$ & IV $(\%)$ & $\mathrm{K}_{\mathrm{ST}}(\%)$ & $\mathrm{K}_{\mathrm{CT}}-\mathrm{R}(\%)$ & $\mathrm{T}_{50}($ hari $)$ \\
\hline Kontrol & $91 \mathrm{bc}$ & $91 \mathrm{bc}$ & 57 & $88 \mathrm{~b}$ & 86,64 & 4,91 \\
SRK 5(1) & $89 \mathrm{bc}$ & $89 \mathrm{bc}$ & 45 & $73 \mathrm{ab}$ & 83,49 & 5,52 \\
SRK 5(2) & $97 \mathrm{c}$ & $97 \mathrm{c}$ & 62 & $82 \mathrm{ab}$ & 107,83 & 5,20 \\
SRK 5(3) & $93 \mathrm{bc}$ & $93 \mathrm{bc}$ & 40 & $79 \mathrm{ab}$ & 90,89 & 5,70 \\
SRK 5(4) & $86 \mathrm{bc}$ & $86 \mathrm{bc}$ & 63 & $83 \mathrm{ab}$ & 93,06 & 5,28 \\
SRK 5(5) & $85 \mathrm{bc}$ & $85 \mathrm{bc}$ & 56 & $78 \mathrm{ab}$ & 85,47 & 5,25 \\
HWI 4(1) & $81 \mathrm{abc}$ & $81 \mathrm{abc}$ & 51 & $75 \mathrm{ab}$ & 84,93 & 5,27 \\
HWI 4(2) & $86 \mathrm{bc}$ & $86 \mathrm{bc}$ & 62 & $83 \mathrm{ab}$ & 92,76 & 5,13 \\
HWI 4(3) & $89 \mathrm{bc}$ & $89 \mathrm{bc}$ & 54 & $76 \mathrm{ab}$ & 91,15 & 5,07 \\
HWI 4(4) & $76 \mathrm{ab}$ & $76 \mathrm{ab}$ & 48 & $65 \mathrm{ab}$ & 79,22 & 4,66 \\
HWI 5(1) & $92 \mathrm{bc}$ & $92 \mathrm{bc}$ & 64 & $84 \mathrm{ab}$ & 98,73 & 4,62 \\
HWI 5(4) & $94 \mathrm{c}$ & $94 \mathrm{c}$ & 61 & $80 \mathrm{ab}$ & 97,67 & 4,74 \\
HWI 8(6) & $88 \mathrm{bc}$ & $88 \mathrm{bc}$ & 66 & $81 \mathrm{ab}$ & 94,90 & 4,54 \\
BS3 4(5) & $87 \mathrm{bc}$ & $87 \mathrm{bc}$ & 49 & $75 \mathrm{ab}$ & 84,84 & 5,25 \\
BS3 5(1) & $92 \mathrm{bc}$ & $92 \mathrm{bc}$ & 54 & $80 \mathrm{ab}$ & 93,43 & 4,89 \\
BS3 5(3) & $83 \mathrm{bc}$ & $83 \mathrm{bc}$ & 39 & $76 \mathrm{ab}$ & 79,77 & 5,70 \\
BS3 5(4) & $88 \mathrm{bc}$ & $88 \mathrm{bc}$ & 56 & $83 \mathrm{ab}$ & 87,76 & 5,18 \\
KTK 8(4) & $84 \mathrm{bc}$ & $84 \mathrm{bc}$ & 43 & $74 \mathrm{ab}$ & 80,96 & 5,39 \\
KTK 8(5) & $65 \mathrm{a}$ & $65 \mathrm{a}$ & 57 & $60 \mathrm{a}$ & 71,98 & 4,53 \\
\hline BNJ 0,05 & 17,09 & 17,09 & - & 24,69 & - & - \\
\hline Keterangan : Angka yang diikuti oleh huruf yang & sama pada kolom yang sama berbeda tidak nyata pada Uji \\
& Beda Nyata Jujur (BNJ) $\alpha=0,05$. & & & &
\end{tabular}

Tabel 3. Rata-rata Nilai Pertumbuhan Bibit Akibat Perlakuan Beberapa Rizobakteri

\begin{tabular}{ccccc}
\hline & \multicolumn{5}{c}{ Tolok Ukur Pertumbuhan Bibit } \\
\cline { 2 - 5 } Rizobakteri & $\begin{array}{c}\text { Tinggi } \\
\text { Bibit }(\mathrm{cm})\end{array}$ & $\begin{array}{c}\text { Jumlah } \\
\text { Daun (helai) }\end{array}$ & $\begin{array}{c}\text { Diameter } \\
\text { Batang }(\mathrm{mm})\end{array}$ & $\begin{array}{c}\text { Berangkasan } \\
\text { Kering }(\mathrm{g})\end{array}$ \\
\hline Kontrol & $41,53 \mathrm{e}$ & $5,83 \mathrm{~b}$ & $3,13 \mathrm{~g}$ & 4,30 \\
SRK 5(1) & $37,75 \mathrm{a}-\mathrm{e}$ & $5,40 \mathrm{ab}$ & $2,96 \mathrm{~g}$ & 5,11 \\
SRK 5(2) & $41,13 \mathrm{de}$ & $5,40 \mathrm{ab}$ & $3,02 \mathrm{~g}$ & 4,97 \\
SRK 5(3) & $40,65 \mathrm{c}-\mathrm{e}$ & $5,48 \mathrm{ab}$ & $3,07 \mathrm{~g}$ & 3,60 \\
SRK 5(4) & $37,60 \mathrm{a}-\mathrm{e}$ & $4,98 \mathrm{ab}$ & $2,05 \mathrm{~b}-\mathrm{e}$ & 4,17 \\
SRK 5(5) & $48,13 \mathrm{f}$ & $4,85 \mathrm{a}$ & $2,75 \mathrm{fg}$ & 3,21 \\
HWI 4(1) & $38,53 \mathrm{~b}-\mathrm{e}$ & $5,18 \mathrm{ab}$ & $2,84 \mathrm{fg}$ & 3,25 \\
HWI 4(2) & $35,18 \mathrm{a}-\mathrm{c}$ & $4,78 \mathrm{a}$ & $2,75 \mathrm{fg}$ & 3,39 \\
HWI 4(3) & $32,68 \mathrm{ab}$ & $4,78 \mathrm{a}$ & $2,63 \mathrm{efg}$ & 3,65 \\
HWI 4(4) & $36,88 \mathrm{a}-\mathrm{e}$ & $4,98 \mathrm{ab}$ & $3,14 \mathrm{~g}$ & 4,36 \\
HWI 5(1) & $38,00 \mathrm{a}-\mathrm{e}$ & $4,88 \mathrm{ab}$ & $2,62 \mathrm{~d}-\mathrm{g}$ & 3,31 \\
HWI 5(4) & $36,83 \mathrm{a}-\mathrm{e}$ & $5,28 \mathrm{ab}$ & $3,04 \mathrm{~g}$ & 3,32 \\
HWI 8(6) & $39,23 \mathrm{c}-\mathrm{e}$ & $4,93 \mathrm{ab}$ & $2,71 \mathrm{fg}$ & 2,40 \\
BS3 4(5) & $38,08 \mathrm{a}-\mathrm{e}$ & $5,20 \mathrm{ab}$ & 6,07 \\
BS3 5(1) & $35,50 \mathrm{a}-\mathrm{d}$ & $4,95 \mathrm{ab}$ & $2,74 \mathrm{fg}$ & 3,49 \\
BS3 5(3) & $41,30 \mathrm{de}$ & $5,50 \mathrm{ab}$ & $2,30 \mathrm{c}-\mathrm{f}$ & 3,01 \\
BS3 5(4) & $36,65 \mathrm{a}-\mathrm{e}$ & $5,28 \mathrm{ab}$ & $2,04 \mathrm{bcd}$ & 3,80 \\
KTK 8(4) & $32,40 \mathrm{a}$ & $5,05 \mathrm{ab}$ & $1,75 \mathrm{abc}$ & - \\
KTK 8(5) & $32,70 \mathrm{ab}$ & $5,65 \mathrm{ab}$ & $1,38 \mathrm{a}$ & $1,71 \mathrm{ab}$ \\
\hline BNJ & 5,89 & 0,95 & 0,58 & \\
\hline
\end{tabular}

Keterangan : Angka yang diikuti oleh huruf yang sama pada kolom yang sama berbeda tidak nyata pada Uji Beda Nyata Jujur (BNJ) $\alpha=0,05$.

Lebih lanjut Khaeruni et al. (2011) mengemukakan bahwa ketiga isolat rizobakteri yang digunakan dalam penelitian ini, selain mampu memproduksi IAA juga memiliki kemampuan sebagai pelarut fosfat dan memfiksasi nitrogen nonsimbiotik. Bhattacharyya dan Jha (2012) yang menyatakan bahwa kemampuan rizobakteri sebagai pemacu pertumbuhan tanaman ditunjukkan dengan kemampuan dalam menyediakan dan memobilisasi penyerapan 
berbagai unsur hara dalam tanah serta mensintesis dan mengubah konsentrasi berbagai fitohormon pemacu pertumbuhan tanaman.

\section{Kemampuan Varietas Terhadap Viabilitas, Vigor Benih dan Pertumbuhan Bibit}

Hasil analisis ragam (Uji F) menunjukkan bahwa perlakuan varietas berpengaruh sangat nyata terhadap keenam tolok ukur yang diamati yaitu potensi tumbuh maksimum (PTM), daya berkecambah (DB), indeks vigor (IV), keserempakan tumbuh $\left(\mathrm{K}_{\mathrm{ST}}\right)$, kecepatan tumbuh relatif $\left(\mathrm{K}_{\mathrm{CT}}-\mathrm{R}\right)$ dan waktu mencapai 50\% $\left(\mathrm{T}_{50}\right)$. Sedangkan pada tolok ukur pertumbuhan bibit, perlakuan varietas berpengaruh sangat nyata terhadap jumlah daun, diameter bantang dan berangkasan kering. Sedangkan parameter tinggi tanaman tidak berpengaruh nyata.

Tabel 4. Rata-rata Nilai Viabilitas dan Vigor Benih Akibat Perlakuan Dua Varietas Tomat

\begin{tabular}{lcccccc}
\hline \multirow{2}{*}{ Varietas } & \multicolumn{7}{c}{ Tolok ukur viabilitas dan vigor benih } \\
\cline { 2 - 7 } & PTM (\%) & DB (\%) & IV $(\%)$ & $\mathrm{K}_{\mathrm{ST}}(\%)$ & $\mathrm{K}_{\mathrm{CT}}-\mathrm{R}(\%)$ & $\mathrm{T}_{50}$ (hari) \\
\hline Lentana & $81,47 \mathrm{a}$ & $81,47 \mathrm{a}$ & $39,89 \mathrm{a}$ & $72,42 \mathrm{a}$ & $77,21 \mathrm{a}$ & $5,67 \mathrm{~b}$ \\
Servo & $91,79 \mathrm{~b}$ & $91,79 \mathrm{~b}$ & $68,21 \mathrm{~b}$ & $82,84 \mathrm{~b}$ & $100,21 \mathrm{~b}$ & $4,52 \mathrm{a}$ \\
\hline \multicolumn{1}{c}{ BNJ 0,05 } & 2,97 & 2,97 & 7,17 & 38,96 & 5,89 & 0,28 \\
\hline
\end{tabular}

Keterangan : Angka yang diikuti oleh huruf yang sama pada kolom yang sama berbeda tidak nyata pada Uji Beda Nyata Jujur (BNJ) $\alpha=0,05$.

Tabel 5. Rata-rata Nilai Pertumbuhan Bibit Akibat Perlakuan Dua Varietas Tomat

\begin{tabular}{lcccc}
\hline \multirow{2}{*}{ Varietas } & \multicolumn{4}{c}{ Tolok Ukur Pertumbuhan Bibit } \\
\cline { 2 - 5 } & $\begin{array}{c}\text { Tinggi } \\
\text { Bibit }(\mathrm{cm})\end{array}$ & $\begin{array}{c}\text { Jumlah } \\
\text { Daun (helai) }\end{array}$ & $\begin{array}{c}\text { Diameter Batang } \\
(\mathrm{mm})\end{array}$ & $\begin{array}{c}\text { Berangkasan } \\
\text { Kering }(\mathrm{g})\end{array}$ \\
\hline Lentana & 38,43 & $4,94 \mathrm{a}$ & $2,45 \mathrm{a}$ & $3,15 \mathrm{a}$ \\
Servo & 37,43 & $5,41 \mathrm{~b}$ & $2,67 \mathrm{~b}$ & $4,64 \mathrm{~b}$ \\
\hline BNJ 0,05 & - & 1,54 & 0,88 & 7,11 \\
\hline
\end{tabular}

Keterangan : Angka yang diikuti oleh huruf yang sama pada kolom yang sama berbeda tidak nyata pada Uji Beda Nyata Jujur (BNJ) $\alpha=0,05$.

Pengaruh varietas terhadap viabilitasn dan vigor benih maupun pertumbuhan bibit tomat berdasarkan deskripsi varietas (Lampiran 4) varietas Lentana pada peubah diameter batang mampu mencapai $15 \mathrm{~mm}$ sedangkan varietas Servo (Lampiran 5) diameter batang dari $10 \mathrm{~mm}-12 \mathrm{~mm}$. Hal ini berbeda dengan nilai rata-rata tolok ukur pembibitan yang diamati varietas Servo dominan lebih baik dibandingkan dengan varietas Lentana. Hasil penelitian sebelumnya melaporkan bahwa perlakuan benih menggunakan rizobakteri pemacu pertumbuhan tanaman hasilnya berbeda-beda terhadap efektivitas peningkatan pertumbuhan bibit berdasarkan varietas yang digunakan (Mardhiah, 2015).

Tingginya nilai jumlah daun dan diameter batang dikarenakan varietas tersebut mampu beradaptasi dengan lingkungan hidupnya, meskipun secara genotipe varietas lain mempunyai potensi yang baik, akan tetapi karena masih dalam tahap beradaptasi nilainya lebih rendah dari pada yang seharusnya. Sehingga berpengaruh pada bobot berangkasan kering tanaman tomat dimana status nutrisi tanaman tersebut sebagai dampak dari laju fotosintesis suatu tanaman dengan tidak mengikut sertakan kadar airnya, semakin besar fotosintat yang ditunjukkan maka pertumbuhan organ tanaman semakin baik sehingga bobot kering tanaman yang akan dihasilkan semakin tinggi (Kartika et al., 2013).

\section{Hubungan Antara Rizobakteri dan Varietas Tomat Terhadap Viabilitas dan Vigor Benih}

Hubungan Antara Rizobakteri dan Varietas Tomat Terhadap Viabilitas dan Vigor Benih dapat dilihat pada Tabel 6 dan 7. 
Tabel 6. Rata-rata Interaksi antara Rizobakteri dan Varietas terhadap Nilai Viabilitas dan Vigor

\begin{tabular}{ccccccc}
\hline \multirow{2}{*}{ Perlakuan } & \multicolumn{5}{c}{ Tolok ukur viabilitas dan vigor benih } \\
\cline { 2 - 6 } & \multicolumn{2}{c}{ PTM $(\%)$} & \multicolumn{2}{c}{ DB $(\%)$} & \multicolumn{2}{c}{ IV (\%) } \\
\cline { 2 - 6 } & Lentana & Servo & Lentana & Servo & Lentana & Servo \\
\hline Kontrol & $88 \mathrm{bA}$ & $94 \mathrm{abA}$ & $88 \mathrm{bA}$ & $94 \mathrm{abA}$ & 42 & 72 \\
SRK 5(1) & $90 \mathrm{bA}$ & $88 \mathrm{abA}$ & $90 \mathrm{bA}$ & $88 \mathrm{abA}$ & 44 & 46 \\
SRK 5(2) & $94 \mathrm{bA}$ & $100 \mathrm{bA}$ & $94 \mathrm{bA}$ & $100 \mathrm{bA}$ & 56 & 68 \\
SRK 5(3) & $94 \mathrm{bA}$ & $92 \mathrm{abA}$ & $94 \mathrm{bA}$ & $92 \mathrm{abA}$ & 26 & 54 \\
SRK 5(4) & $82 \mathrm{bA}$ & $90 \mathrm{abA}$ & $82 \mathrm{bA}$ & $90 \mathrm{abA}$ & 48 & 78 \\
SRK 5(5) & $74 \mathrm{bA}$ & $96 \mathrm{bA}$ & $74 \mathrm{bA}$ & $96 \mathrm{bA}$ & 40 & 72 \\
HWI 4(1) & $70 \mathrm{abA}$ & $92 \mathrm{abA}$ & $70 \mathrm{abA}$ & $92 \mathrm{abA}$ & 22 & 80 \\
HWI 4(2) & $76 \mathrm{bA}$ & $96 \mathrm{bA}$ & $76 \mathrm{bA}$ & $96 \mathrm{bA}$ & 50 & 74 \\
HWI 4(3) & $82 \mathrm{bA}$ & $96 \mathrm{bA}$ & $82 \mathrm{bA}$ & $96 \mathrm{bA}$ & 36 & 72 \\
HWI 4(4) & $84 \mathrm{bA}$ & $68 \mathrm{aA}$ & $84 \mathrm{bA}$ & $68 \mathrm{aA}$ & 46 & 50 \\
HWI 5(1) & $88 \mathrm{bA}$ & $96 \mathrm{bA}$ & $88 \mathrm{bA}$ & $96 \mathrm{bA}$ & 50 & 78 \\
HWI 5(4) & $90 \mathrm{bA}$ & $98 \mathrm{bA}$ & $90 \mathrm{bA}$ & $98 \mathrm{bA}$ & 52 & 70 \\
HWI 8(6) & $78 \mathrm{bA}$ & $98 \mathrm{bA}$ & $78 \mathrm{bA}$ & $98 \mathrm{bA}$ & 42 & 90 \\
BS3 4(5) & $84 \mathrm{bA}$ & $90 \mathrm{abA}$ & $84 \mathrm{bA}$ & $90 \mathrm{abA}$ & 38 & 60 \\
BS3 5(1) & $92 \mathrm{bA}$ & $92 \mathrm{abA}$ & $92 \mathrm{bA}$ & $92 \mathrm{abA}$ & 38 & 70 \\
BS3 5(3) & $74 \mathrm{bA}$ & $92 \mathrm{abA}$ & $74 \mathrm{bA}$ & $92 \mathrm{abA}$ & 26 & 52 \\
BS3 5(4) & $82 \mathrm{bA}$ & $94 \mathrm{abA}$ & $82 \mathrm{bA}$ & $94 \mathrm{abA}$ & 36 & 76 \\
KTK 8(4) & $80 \mathrm{bA}$ & $88 \mathrm{abA}$ & $80 \mathrm{bA}$ & $88 \mathrm{abA}$ & 30 & 56 \\
KTK 8(5) & $46 \mathrm{aA}$ & $84 \mathrm{abB}$ & $46 \mathrm{aA}$ & $84 \mathrm{abB}$ & 36 & 78 \\
\hline BNJ 0,05 & \multicolumn{7}{c}{27,04} & & - \\
\hline
\end{tabular}

Keterangan : Angka yang diikuti oleh huruf yang sama pada kolom yang sama berbeda tidak nyata pada taraf 0,05 (Uji BNJ). Huruf kecil dibaca vertikal dan huruf besar dibaca horizontal.

Tabel 7. Rata-rata Interaksi antara Rizobakteri dan Varietas terhadap Nilai Viabilitas dan Vigor

\begin{tabular}{|c|c|c|c|c|c|c|}
\hline \multirow{3}{*}{ Perlakuan } & \multicolumn{6}{|c|}{ Tolok ukur viabilitas dan vigor benih } \\
\hline & \multicolumn{2}{|c|}{$\mathrm{K}_{\mathrm{ST}}(\%)$} & \multicolumn{2}{|c|}{$\mathrm{K}_{\mathrm{CT}}-\mathrm{R}(\%)$} & \multicolumn{2}{|c|}{$\mathrm{T}_{50}$ (hari) } \\
\hline & Lentana & Servo & Lentana & Servo & Lentana & Servo \\
\hline Kontrol & $82 \mathrm{bA}$ & $94 \mathrm{aA}$ & 80,79 & 92,49 & 4,81 & 3,92 \\
\hline SRK 5(1) & $80 \mathrm{abA}$ & $66 \mathrm{aA}$ & 84,07 & 82,91 & 4,88 & 4,09 \\
\hline SRK 5(2) & $82 \mathrm{bA}$ & $82 \mathrm{aA}$ & 94,81 & 120,85 & 4,95 & 4,11 \\
\hline SRK 5(3) & $82 \mathrm{bA}$ & $76 \mathrm{aA}$ & 84,52 & 97,25 & 4,99 & 4,17 \\
\hline SRK 5(4) & $76 \mathrm{bA}$ & $90 \mathrm{aA}$ & 86,17 & 99,95 & 5,00 & 4,25 \\
\hline SRK 5(5) & $70 \mathrm{abA}$ & $86 \mathrm{aA}$ & 63,75 & 107,18 & 5,41 & 4,31 \\
\hline HWI 4(1) & $60 \mathrm{abA}$ & $90 \mathrm{aA}$ & 60,99 & 108,87 & 5,54 & 4,36 \\
\hline HWI 4(2) & $74 \mathrm{abA}$ & $92 \mathrm{aA}$ & 78,03 & 107,49 & 5,55 & 4,42 \\
\hline HWI 4(3) & $62 \mathrm{abA}$ & $90 \mathrm{aA}$ & 72,58 & 109,71 & 5,56 & 4,43 \\
\hline HWI 4(4) & $72 \mathrm{abA}$ & $58 \mathrm{aA}$ & 81,97 & 76,48 & 5,68 & 4,50 \\
\hline HWI 5(1) & $76 \mathrm{abA}$ & $92 \mathrm{aA}$ & 86,58 & 110,88 & 5,86 & 4,54 \\
\hline HWI 5(4) & $80 \mathrm{abA}$ & $80 \mathrm{aA}$ & 88,21 & 107,13 & 5,86 & 4,54 \\
\hline HWI 8(6) & $68 \mathrm{abA}$ & $94 \mathrm{aA}$ & 76,21 & 113,59 & 5,95 & 4,59 \\
\hline BS3 4(5) & $72 \mathrm{abA}$ & $78 \mathrm{aA}$ & 77,21 & 92,46 & 6,13 & 4,60 \\
\hline BS3 5(1) & $80 \mathrm{abA}$ & $80 \mathrm{aA}$ & 86,34 & 100,51 & 6,25 & 4,68 \\
\hline BS3 5(3) & $68 \mathrm{abA}$ & $84 \mathrm{aA}$ & 67,08 & 92,45 & 6,29 & 4,84 \\
\hline BS3 5(4) & $82 \mathrm{abA}$ & $84 \mathrm{aA}$ & 77,78 & 97,74 & 6,31 & 5,05 \\
\hline KTK 8(4) & $68 \mathrm{abA}$ & $80 \mathrm{aA}$ & 72,50 & 89,42 & 6,33 & 5,08 \\
\hline KTK 8(5) & $42 \mathrm{aA}$ & $78 \mathrm{aA}$ & 47,31 & 96,64 & 6,36 & 5,48 \\
\hline BNJ 0,05 & \multicolumn{2}{|c|}{38,96} & \multicolumn{2}{|c|}{ - } & \\
\hline
\end{tabular}

Keterangan : Angka yang diikuti oleh huruf yang sama pada kolom yang sama berbeda tidak nyata pada taraf 0,05 (Uji BNJ). Huruf kecil dibaca vertikal dan huruf besar dibaca horizontal.

Tabel 6 dan 7 menunjukkan bahwa berdasarkan perlakuan tolok ukur viabilitas dan vigor benih, Interaksi antara rizobakteri dan varietas berpengaruh sangat nyata terhadap potensi tumbuh maksimum (PTM), dan daya berkecambah (DB). Sementara berpengaruh nyata pada tolok ukur keserempakan tumbuh $\left(\mathrm{K}_{\mathrm{ST}}\right)$. Sedangkan pada tolok ukur indeks vigor 
(IV), kecepatan tumbuh relatif $\left(\mathrm{K}_{\mathrm{CT}}-\mathrm{R}\right)$ dan waktu mencapai $50 \%\left(\mathrm{~T}_{50}\right)$ berpengaruh tidak nyata terhadap interaksi rizobakteri dan varietas. Namun, pada tolok ukur pertumbuhan bibit (Tabel 8) interaksi antara rizobakteri dan varietas menunjukkan berpengaruh sangat nyata pada tinggi tanaman, jumlah daun dan diameter batang serta tidak berpengaruh nyata terhadap berangkasan kering.

Tabel 8. Rata-rata Interaksi antara Rizobakteri dan Varietas terhadap Pertumbuhan Bibit

\begin{tabular}{|c|c|c|c|c|c|c|c|c|}
\hline \multirow{3}{*}{ Perlakuan } & \multicolumn{8}{|c|}{ Tolok ukur Pertumbuhan Bibit } \\
\hline & \multicolumn{2}{|c|}{$\begin{array}{l}\text { Tinggi } \\
\text { Bibit }\end{array}$} & \multicolumn{2}{|c|}{$\begin{array}{c}\text { Jumlah } \\
\text { Daun }\end{array}$} & \multicolumn{2}{|c|}{$\begin{array}{c}\text { Diameter } \\
\text { Batang }\end{array}$} & \multicolumn{2}{|c|}{$\begin{array}{c}\text { Berangkasan } \\
\text { Kering }\end{array}$} \\
\hline & Lentana & Servo & Lentana & Servo & Lentana & Servo & Lentana & Servo \\
\hline Kontrol & $15,29 \mathrm{aA}$ & $18,68 \mathrm{aA}$ & $5,95 \mathrm{aA}$ & $6,15 \mathrm{aA}$ & 3,39 & 1,47 & 2,21 & 1,76 \\
\hline \multirow{2}{*}{$\begin{array}{l}\text { SRK 5(1) } \\
\text { SRK 5(2) }\end{array}$} & $17,21 \mathrm{abA}$ & $18,71 \mathrm{abA}$ & $6,30 \mathrm{aA}$ & $6,30 \mathrm{aA}$ & 1,76 & 2,06 & 2,00 & 2,71 \\
\hline & $\begin{array}{l}18,59 \\
\text { abcA }\end{array}$ & $19,25 \mathrm{abA}$ & $6,30 \mathrm{aA}$ & $6,60 \mathrm{abA}$ & 2,49 & 2,17 & 2,82 & 4,01 \\
\hline SRK 5(3) & $19,55 \mathrm{a}-\mathrm{dA}$ & $19,97 \mathrm{abA}$ & $6,40 \mathrm{aA}$ & $6,70 \mathrm{abA}$ & 2,11 & 2,46 & 2,11 & 2,30 \\
\hline SRK 5(4) & $20,15 \mathrm{a}-\mathrm{dA}$ & $19,98 \mathrm{abA}$ & $6,50 \mathrm{aA}$ & $6,80 \mathrm{abA}$ & 2,00 & 2,33 & 2,02 & 4,57 \\
\hline SRK 5(5) & 21,02 a-eA & $20,11 \mathrm{abA}$ & $6,70 \mathrm{aA}$ & $6,95 \mathrm{abA}$ & 2,26 & 2,25 & 2,57 & 4,04 \\
\hline HWI 4(1) & 21,93 a-fA & $21,03 \mathrm{abA}$ & $6,70 \mathrm{aA}$ & $7,00 \mathrm{abA}$ & 2,31 & 1,98 & 2,51 & 3,15 \\
\hline HWI 4(2) & 24,16 a-fA & $24,88 \mathrm{abA}$ & $6,80 \mathrm{aA}$ & $7,20 \mathrm{abA}$ & 2,11 & 2,31 & 2,49 & 2,56 \\
\hline HWI 4(3) & 24,80 a-fA & $25,74 \mathrm{abA}$ & $6,90 \mathrm{aA}$ & $7,20 \mathrm{abA}$ & 2,58 & 1,85 & 4,06 & 2,35 \\
\hline HWI 4(4) & $26,48 \mathrm{~b}-\mathrm{gA}$ & $26,05 \mathrm{abA}$ & $7,00 \mathrm{aA}$ & $7,25 \mathrm{abA}$ & 1,98 & 1,73 & 2,86 & 1,95 \\
\hline HWI 5(1) & $26,53 \mathrm{~b}-\mathrm{gA}$ & $26,55 \mathrm{abA}$ & $7,05 \mathrm{aA}$ & $7,35 \mathrm{abA}$ & 2,01 & 1,72 & 3,26 & 2,23 \\
\hline HWI 5(4) & $27,90 \mathrm{c}-\mathrm{gA}$ & $27,28 \mathrm{abA}$ & $7,30 \mathrm{aA}$ & $7,45 \mathrm{abA}$ & 1,78 & 1,63 & 2,10 & 2,41 \\
\hline HWI 8(6) & $28,25 \mathrm{c}-\mathrm{gA}$ & $28,13 \mathrm{abA}$ & $7,50 \mathrm{aA}$ & $7,60 \mathrm{abA}$ & 2,32 & 2,93 & 1,65 & 4,24 \\
\hline BS3 4(5) & 28,70 d-gA & $28,25 \mathrm{abA}$ & $7,60 \mathrm{aA}$ & $7,75 \mathrm{abA}$ & 2,64 & 2,60 & 2,53 & 3,21 \\
\hline BS3 5(1) & 28,78 d-gA & $30,25 \mathrm{bA}$ & $7,65 \mathrm{aA}$ & $7,80 \mathrm{abA}$ & 2,85 & 2,82 & 2,89 & 2,44 \\
\hline BS3 5(3) & 30,63 efgA & $32,68 \mathrm{bA}$ & $7,70 \mathrm{aA}$ & $7,95 \mathrm{abA}$ & 2,60 & 3,02 & 2,14 & 3,41 \\
\hline BS3 5(4) & $31,35 \mathrm{fgA}$ & $32,73 \mathrm{bA}$ & $7,80 \mathrm{aA}$ & 7,95 abA & 4,17 & 2,88 & 2,74 & 3,48 \\
\hline KTK 8(4) & $31,85 \mathrm{fgA}$ & $33,00 \mathrm{bA}$ & $7,95 \mathrm{aA}$ & $9,35 \mathrm{bA}$ & 2,86 & 2,93 & 2,93 & 2,96 \\
\hline KTK 8(5) & $35,33 \mathrm{gA}$ & $33,68 \mathrm{bA}$ & $8,00 \mathrm{aA}$ & $9,65 \mathrm{bA}$ & 2,71 & 3,00 & 3,57 & 3,84 \\
\hline BNJ 0,05 & \multicolumn{2}{|c|}{10,08} & \multicolumn{2}{|c|}{3,08} & \multicolumn{2}{|c|}{-} & \multicolumn{2}{|c|}{-} \\
\hline
\end{tabular}

Sutiriati (2012) melaporkan bahwa isolat rizobakteri jenis Bacillus, P. fluorescens dan Serratia menunjukkan performa lebih baik dibandingkan dengan kontrol dan isolat lainnya serta mampu memperbaiki viabilitas dan vigor benih. Rizobakteri indegenus juga mampu meningkatkan kecepatan tumbuh relatif dan waktu yang dibutuhkan untuk mencapai 50\% perkecambahan $\left(\mathrm{T}_{50}\right)$. Hal ini disebabkan oleh rizobakteri yang mampu memproduksi hormon IAA dalam berbagai jenis rizobakteri dan kemampuan masing-masing dalam mengolonisasi perakaran tanaman (Thakuria et al., 2004).

Pada paremeter tinggi bibit, varietas Servo memiliki respon tinggi tanaman yang terbaik dibandingkan dengan varietas Lentana. Ini kerena varietas servo dapat beradaptasi dengan mudah dan cepat baik di dataran rendah maupun di dataran tinggi (Tukimin et al., 2015). Salisbury dan Ross (1995) menambahkan, setiap varietas memiliki ketahanan yang berbeda, beberapa tanaman dapat melakukan adaptasi dengan cepat, namun ada tanaman baru dapat beradaptasi dengan lingkungan dalam waktu yang sangat lama.

\section{KESIMPULAN}

Rizobakteri yang efektif menghambat patogen R.solani secara in vitro terdapat pada isolat HWI 4(4), HWI 5(1), HWI 5(4), HWI 8(6) dan BS3 4(5) dengan masing-masing persentase $52,59 \%, 54,21 \%, 56,61 \%, 57,63 \%$, dan $54,01 \%$. Sedangkan rizobakteri terhadap 
patogen S.rolfsii memiliki daya hambat rendah $(<50 \% \mathrm{DH})$. Rizobakteri yang efektif yang efektif terhadap peningkatan viabilitas dan vigor benih pada potensi tumbuh maksimum, daya berkecambah dan keserempakan tumbuh terdapat pada isolat SRK 5(3) dan HWI 5(4). Viabilitas dan vigor benih varietas Servo lebih unggul dibandingkan varietas Lentana. Rizobakteri berpengaruh pada pembibitan tomat yaitu tinggi tanaman, jumlah daun, dan diameter batang pada isolat SRK 5(5) dan HWI 4(4). Pada tinggi bibit varietas Lentana lebih baik dari pada varietas Servo, namun pada jumlah daun dan diameter batang lebih besar dijumpai pada varietas Servo.

\section{DAFTAR PUSTAKA}

Achmad dan E. P. Sari. 2009. Pengaruh media terhadap pertumbuhan cendawan Fusarium oxysporum. Buletin RISTRI. 1 (4): 159-160.

Ainy, E. Q., R. Restiyani dan S. Lela. 2015. Uji aktivitas antagonis trichoderma harzianum terhadap Colletotrichum capsici dan Colletotrichum acutatum penyebab antraknosa pada tanaman cabai. Seminar Nasional XII Pendidikan Biologi FKIP UNS 2015. Hal: 893-894.

Bai, Y., B. Pan., T. C. Charles and D. L. Smith. 2002. Coinoculation dose and root zone temperature for plant growth promoting rhizobacteria on soybean (Glycine max L.) grown in soil-less media. Soil Biol Biochem. 34: 1953-1957.

Cahyono, B. 2008. Usaha Tani dan Penanganan Pascapanen. Kanisius, Yogyakarta.

Khaeruni, A., G. A. K. Sutariati., S. Wahyuni. 2010. Karakterisasi dan uji aktivitas bakteri rizosfer lahan ultisol sebagai pemacu pertumbuhan dan agensia hayati cendawan patogen tular tanah secara in-vitro. Hama Penyakit Tumbuhan Trop. 10(2) : 123-30.

Mardiah. 2015. Perlakuan benih menggunakan rizobakteri pemacu pertumbuhan tanaman terhadap viabilitas dan vigor benih, pertumbuhan bibit dan pertumbuhan vegetatif serta produksi tanaman cabai merah (Capsicum annuиm L). Tesis. Program Studi Magister Agroekoteknologi. Program Pascasarjana. Universitas Syiah Kuala, Banda Aceh.

Pulungan, D. M. S., Haryati, dan Lahay, R. R. 2014. Pengaruh periode panen terhadap viabilitas benih rosela (Hibiscus sabdariffa L.). Jurnal Online Agroekoteknologi. 2(2) : $878-883$.

Sutariati G.A.K., L. O. Safuan dan A. Wahab. 2012 Karakter Fisiologis dan Kemangkusan Rizobakteri Indigenus Sulawesi Tenggara sebagai Pemacu Pertumbuhan Tanaman Cabai. J Hort. 22(1):57-64.

Syamsuddin. 2010. Perlakuan benih untuk pengendalian penyakit busuk phytophthora, peningkatan hasil dan mutu benih cabai merah (Capsicum annuum L). Disertasi. Sekolah Pascasarjana Institut Pertanian Bogor. Bogor. 201 hal.

Thakuria, D., N.C. Talukdar., C. Goswami., S. Hazarika., R.C. Boro and M.R. Khan. 2004. Characterization and screening of bacteria from rhizosphere of rice grown in acidic soils of Assam. Current Sci. 86:978-985. 